\author{
S.O. Tsybulnyk ${ }^{*}$ \\ Igor Sikorsky Kyiv Polytechnic Institute, Kyiv, Ukraine
}

\title{
SOFTWARE FOR MULTI-SITE DAMAGE VISUALIZATION
}

Background. In our time, the improvement of diagnostic systems is mainly focused on increasing the accuracy of primary transducers. Standard methods of displaying diagnostic information do not always allow us to uniquely assess the technical state of objects. The implementation of new ways of measurements visualizing using the latest information and computer technologies, for example, simulation and motion capture systems, is a promising direction for the development of tools for monitoring and diagnostic of technical state of engineering objects that are in difficult operating conditions.

Objective. The aim of the paper is substantiation and development of software for measurement data visualization for multi-class diagnostic system of technical condition of engineering objects.

Methods. Processing programming language is a new, yet powerful software development tool, including for nextgeneration diagnostic systems.

Results. The algorithm and the software for visualization of complex measurements of stresses and spatial position are developed. It provides the processing (transformation) of the recorded in the output file data for correct display on the simulation model of the tank, taking into account file data write characteristics, ADC parameters (bit rate, input range), the number of information sensors that affects the number of elements of a three-dimensional model for displaying data.

Conclusions. On the basis of the programming language Processing, which allows working with three-dimensional graphics, a program for displaying strain gauge measurements data, pre-recorded into a file, on a geometric model of an object is implemented, as well as displaying the current spatial position of the object by visualizing the measured angles of the slope of the structure relative to the vertical axis.

Keywords: multi-site damage; multi-class diagnostic system; simulation; Processing.

\section{Introduction}

Monitoring of the technical state (TS) of tanks with environmentally hazardous substances requires an integrated approach on the basis of development and application of diagnostic models of the object for the determination and prediction of the characteristics of the stress-strain state in real conditions of operation, as well as the most effective for this object methods and technical means of control and diagnostics.

The classical methods for calculating structural elements for strength are based on the assumption that there are no macroscopic defects in the material during the material lifetime, which could lead to the destruction of the structure [1]. But such an approach is insufficient in solving the problems of ensuring the safe operation of objects with initial defects in their structural elements. Defects and damage in structural elements of vertical steel tanks (VST) arise both as a result of technological and industrial factors, and in the process of exploitation of the structure under the influence of uncontrolled loads of man-made and/or natural origin.
At the present stage, the problems of storing environmentally hazardous substances go beyond national boundaries and have a global character, since some of the objects are beyond the scope of national jurisdiction, for example, in such hard-toreach places as Antarctic region. Such facilities include the cylindrical VST for storage of diesel fuel, which was installed at the beginning of 2007 at the Ukrainian Antarctic Akademik Vernadsky station. For such an object, there are characteristic features: difficult access, critical climatic conditions, significant dynamic disturbances in the form of wind and seismic loads.

This object represents, on the one hand, the most stringent requirements for the safe operation of the VST and, on the other hand, the most adverse, critical operating conditions and the possibilities for monitoring its TS. Therefore, ensuring the safe operation of tanks with environmentally hazardous substances, which are located in hardto-reach places and under the influence of loads of natural and/or technogenic origin, including tank on Vernadsky station, is an important problem that can be solved by monitoring and diagnosing the current TS using modern diagnostic systems.

\footnotetext{
* corresponding author: tsybulnik.s.a@gmail.com
} 
In our time, the improvement of diagnostic systems is mainly focused on increasing the accuracy of the primary transducers. Also in recent years, the use of advanced technologies for the development of diagnostic systems or their component parts (blocks) is considered more often. Works [2-4] can be considered as an example. In these works, systems based on the technology of neural networks (mainly for the monitoring of landslide processes) have been developed. However, these systems can be adapted to monitor the TS of buildings and engineering structures.

The implementation of new ways of these measurements visualizing using the latest information and computer technologies, for example, simulation [5] and motion capture systems [6-9], is a promising direction for the development of tools for monitoring and diagnostic of TS of engineering objects that are in difficult operating conditions. These technologies are not commonly used in measuring tools and systems. Therefore, in order to improve monitoring and diagnostic systems, it is important to find and implement methods for displaying measurement results using the capabilities of modern software.

The main result of the work should be the display of complex measurement data in a convenient for understanding form. This is necessary in order for the operator-person, even without specific analysis skills, to make the correct conclusion about the object's TS.

\section{Problem statement}

Developed over the last decade methods and technologies of diagnosing both individual elements of constructions and complex engineering objects, which are in critical operating conditions, allow to create diagnostic systems of a new class - complex intelligent systems of multi-class diagnostics of structures. The requirements for ensuring a high level of probability of localization of defects and recognition of the current technical state of such systems, as well as the availability of a large number of source information, cause the creation of new effective ways of visualizing these measurements.

Such standard methods for visualizing diagnostic information as histograms and graphs do not always allow the location of excessive strains, cracks or defects that arise in a control object to be quickly and effectively localized. Therefore, the purpose of the work is the substantiation and development of algorithm and software for improvement (based on the simulation) visualization sub- system of the measurements results for the multiclass diagnostics system.

\section{Algorithm and software}

On the basis of the development and complex use of methods and tools for non-destructive testing, the combination of specific mathematical models and methods for operative identification of vibration, deformation and strength processes in the conditions of direct measurements, an automated multi-class diagnostic system (SMD) was developed [10].

The developed SMD solves the diagnostic problem of the forecast estimation of the TS of the object in the early stages of destructive processes development by constructing trends with extrapolation of results for each individual diagnostic parameter. This allows the implementation of a set of measures to prevent the destruction of the object. The main differences of this SMD from such systems are: complexity, multichannel, data visualization subsystem on the basis of simulation.

The data visualization subsystem requires the creation of specialized software. The main purpose of the visualization program of stress measurements and angular position of objects should be processing (transformation) of the recorded into a source file data for correct display on the simulation model, taking into account file data write characteristics, ADC parameters (bit rate, input range), the number of information sensors that affects the number of elements of a three-dimensional model for displaying data and so on. The algorithm of the software of complex measurements of stress and angular position of objects visualization in accordance with the above-mentioned functional capabilities is shown in Fig. 1 [5].

To create software based on the developed algorithm it is necessary to use one of the programming languages. Programming languages, like human languages, are combined into groups of related languages. Processing is a dialect of a Java programming language [11]; it has almost the same syntax, but is supplemented by special commands for working with graphics and external devices. Like any software, Processing consists of a large number of components that work together. It can be used for both simple products and for detailed research. There are more than 100 extension libraries that allow Processing to be used for sound processing, research in the field of machine vision and technical calculations. Processing graphics related to the PostScript system, which served as the basis for the PDF format and OpenGL. 


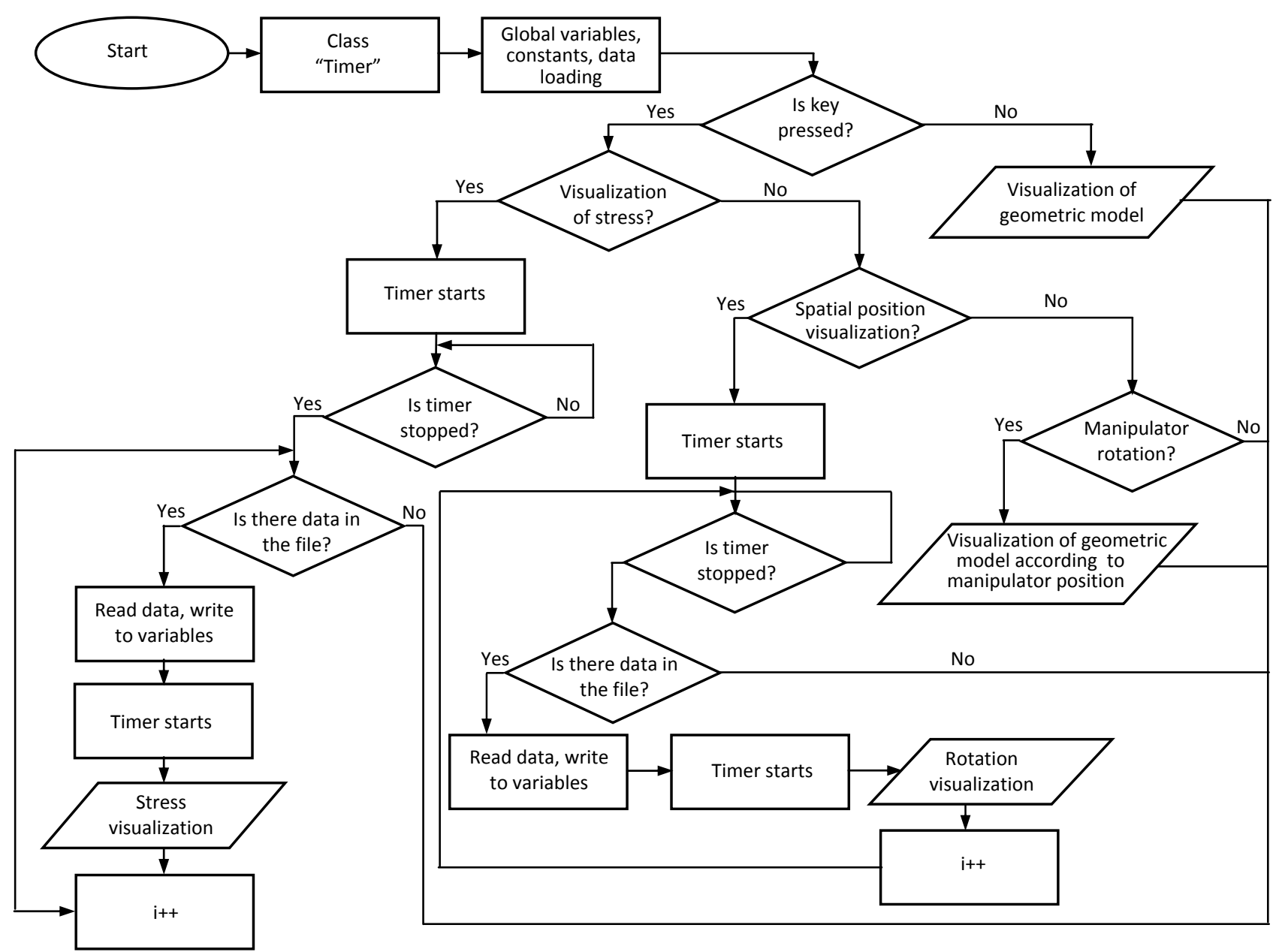

Fig. 1. Algorithm of data visualization software for complex measurements of stresses and angular position of objects

Due to the large number of advantages, the broad functionality and ease of use of the finished program, the Processing language was chosen to create the main part of the software for visualization of strain gauge and survey measurements.

The physical model of the object was used to investigate the effectiveness of the developed software. As a physical model of object, a vertical cylindrical steel tank with $0.04 \mathrm{~m}^{3}$ volume was chosen [10]. Tanks of this type are most often used for the storage of environmentally hazardous substances, such as: oil or petroleum products, chemicals, toxic substances, gases. For this physical model of the tank, a simplified three-dimensional model was created in the CATIA CAD-system. Simplification of the model is to exclude consideration of some elements of the design to optimize the "calculation time"/"accuracy of results" ratio in simulation. Geometric models of additional structural elements or known stress concentrators can be stored in an element base and introduced into the main model as needed.
The object model consists of five belts and five rigidity ribs alternating between each other. The rigidity ribs are made in the form of one element of the design, and each belt is divided into four equal parts (segments), on each of which will be installed strain gauge. Consequently, the total of twenty structural elements (five belts of four elements each) must be used to visualize the stresses on a three-dimensional model. In general, the geometric model of the VST consists of twentyseven elements, taking into account the ribs, the bottom and the sixth belt (for fixing the lid).

The CATIA graphical package has a *.CATProduct extension, but because of the features used in the program library, this model needs to be converted to the *.obj extension. This action can be performed using other geometric modeling tools such as: Autodesk Maya, Autodesk 3ds Max, and other programs that have advanced file saving and exporting capabilities.

3ds Max (3D Studio Max) is a full-featured professional program for creating and editing $3 \mathrm{D}$ 
graphics and animations developed by Autodesk. It contains tools for artists and professionals in the field of multimedia and works in 32-bit and 64-bit Microsoft Windows operating systems.

Despite all the benefits of this program, the mechanisms for creating a model for multi-element VST are quite complicated, so building a geometric model in the CATIA software and its subsequent import into 3ds Max is a rational step.

Each program in Processing language is executed 60 times per second, if this frequency was not limited by the programmer manually. Therefore, due to the discreteness of the data, 60 counts of the signal will be displayed every second and the analysis of the results will not be possible for the human operator. Thus, it is necessary to further develop a timer to delay the image on the screen.

After the program code was complemented by the timer, the debugging of the program was performed, which resulted in the removal of errors and minor modifications to the code in order to facilitate the work with the program. Configuration and validation of the program were carried out using pre-existing data. In this regard, the methodology for verifying the efficiency of the code, responsible for visualizing strain gauge measurements, consisted of the following steps [5]:

1) The test data is generated in the mathematical package MATLAB as random integers from 0 to 50 arbitrary units. Arbitrary unit is an abstract value that corresponds to a certain fixed level of stress.

2) The scale of the result is broken down for example on 5 equal intervals corresponding to a certain state of the geometric model, which determines its color:

a) 0-10 arbitrary units. Safe operation of the structure, the stresses do not exceed the permissible values, there is no need for additional control of the corresponding segment. Displayed in blue;

b) 11-20 arbitrary units. Safe operation of the structure, increased stress, which is still within the permissible limits, there is no need for additional control of the corresponding segment. Displayed in green;

c) 21-30 arbitrary units. Risk is increased, stresses insignificantly exceed the allowable values, there is the possibility of residual deformation, there is a need for additional measures to reduce the level of stress within the corresponding segments. Displayed in yellow;

\footnotetext{
${ }^{*}$ The color figures see at:

http://bulletin.kpi.ua/article/view/126466
}

d) 31-40 arbitrary units. Dangerous operation of the structure, the stresses largely exceed the allowable values, within the corresponding regions there is residual deformation, the possibility of rapid development and instantaneous cracking, the need for additional control by instrumental methods for the localization of concentration zones of stresses within the corresponding segments, the need for measures to strengthen the design and reduce the level of stress. Displayed in orange;

e) 41-50 arbitrary units. Emergency condition, high probability of instantaneous failure of the relevant segments due to the disclosure of cracks, the destruction of welds, etc., the need for complete decommissioning of the object and the search for stress concentration zones within the corresponding segments using instrumental methods, the implementation of measures to replace individual elements, strengthening the structure and reducing the level of stress or full utilization of the object. Displayed in red.

3) To test the conformity of the generated data with the results of visualization of strain gauge measurements, two cases of test data are considered:

a) checking all the intervals with the same type of data (Fig. 2,a), the input data file is generated that within each belt of the object stress in the arbitrary units does not exceed the corresponding limits;

b) checking all the intervals by random data (Fig. 2,b), the file contains random values of the stresses from 0 to 50 arbitrary units for each element of the design.

4) Part (3) was repeated several times for a different combination of generated data.

As a result of configuring, part of the code responsible for strain gauge measurements visualization works without deficiencies. Also in the program window, the color scale and the corresponding stress level for each interval were additionally added. Depending on the actual data (the number of primary transducers, their location, stresses values, calculated limits, etc.), the program code can be changed or expanded to more accurately match the tasks.

The methodology for verifying the efficiency of the code, responsible for visualizing survey measurements, consisted of the following steps [5]:

1) To check the conformity of the generated data with the results of visualization of the angular position, two cases of test data are considered:

a) checking the angular displacement on each axis separately (Fig. 3,a), the input data file is ge- 


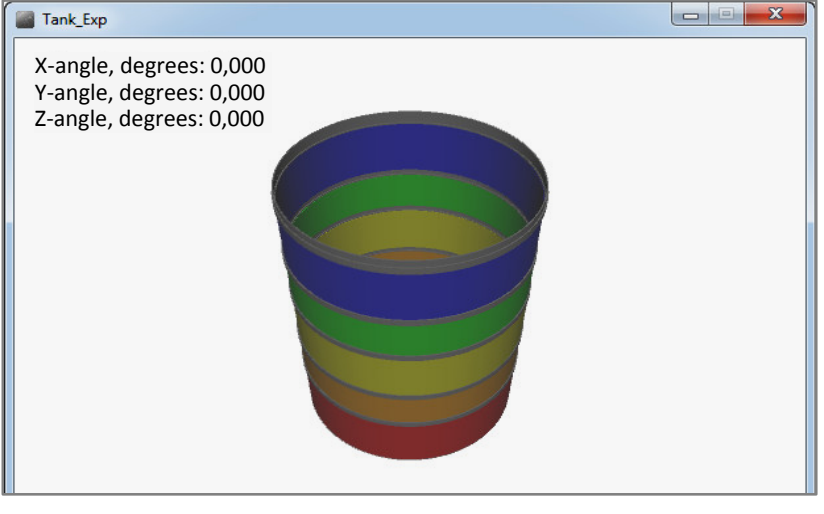

$a$

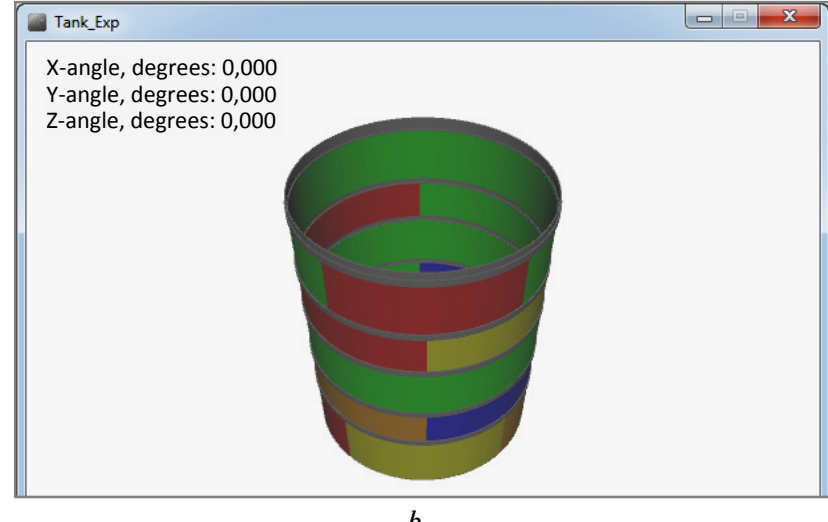

Fig. 2. Strain gauge data visualization results $(a)$ intervals separated by individual belts and $(b)$ random data values

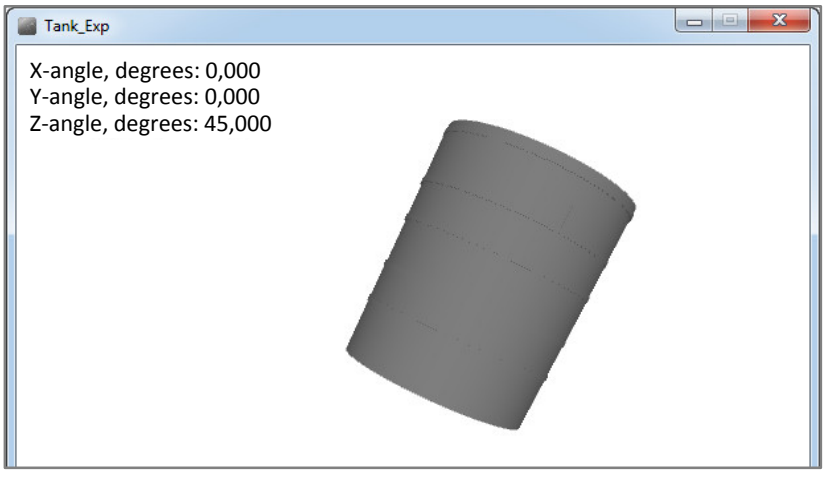

a

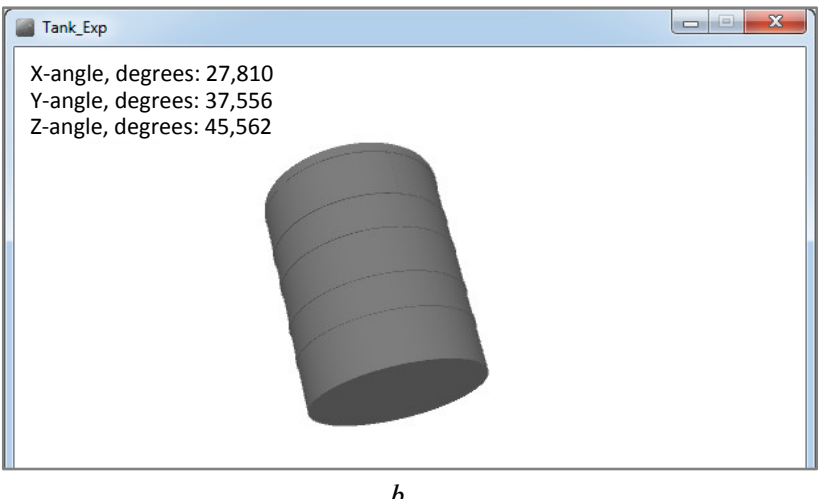

$b$

Fig. 3. Verification of the angular displacement of the geometric model $(a)$ on one axis and $(b)$ on the three axes at the same time

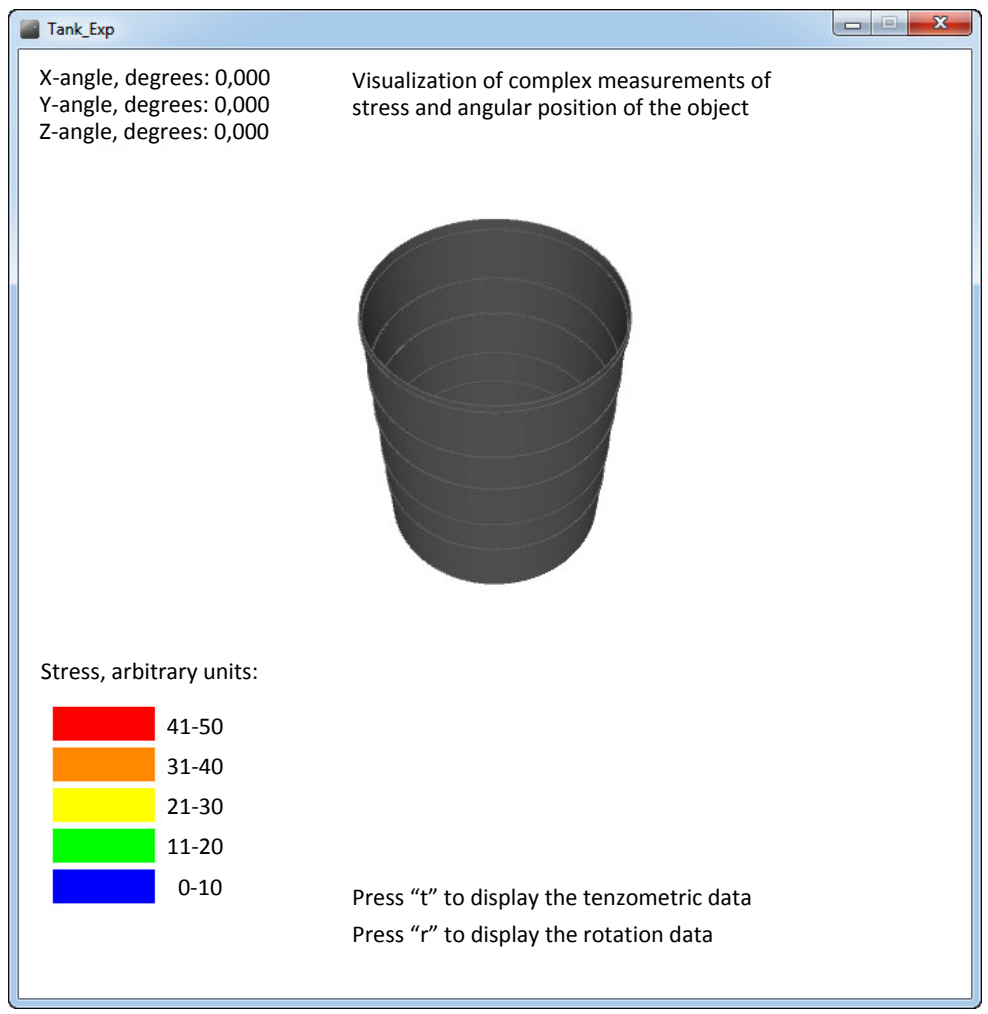

Fig. 4. Main window 
nerated in such a way that within one visualization it contains the angles of inclination of the object only by one axis;

b) checking the angular displacement of the three axes at the same time (Fig. 3, b), the file contains random values of the angles of inclination of the object across all axes within a single visualization.

2) Part (1) was repeated several times for a different combination of generated inputs.

The final appearance of the main window is shown in Fig. 4.

As a result of debugging the part of the code responsible for visualizing the angular position, in the text of the program, a code was added that clears the angular displacement variables for each axis by repeatedly pressing the " $r$ " key and after displaying the last values from the file. Prior to this, the data remained in the variables and could lead to incorrect visualization.

\section{Conclusions}

On the basis of the Processing programming language, which allows working with threedimensional graphics, the software of displaying pre-recorded into a file strain gauge measurements data on the geometric model of the object has been implemented. Five intervals of test data have been selected: $0-10$ arbitrary units, 11-20 arbitrary units, 21-30 arbitrary units, 31-40 arbitrary units, 41-50 arbitrary units. Each gap is displayed with its color on the geometric model of the object. The developed software also allows visualization of the inclination angles (the values of which are prerecorded in the file) of the object simultaneously on three axes.

The developed data visualization program of complex measurements of stresses and angular position of objects works without crashes and can be recommended for testing and use in diagnostic equipment, in particular in SMD. It is expedient to use the developed software (with necessary extensions) for the continuous on-line visualization of the measured data directly from the primary transducers. The software is designed in such a way that a person without specialized analysis skills will be able to diagnose the technical condition of the object.

In future studies, it is necessary to develop an algorithm for automating the change of a geometric model when visualizing various measurement results, for example, vibration and stress. It is also need to consider creating a dynamic model that will reflect any changes in the technical condition of the object.

\section{References}

[1] I. Birger and R. Mavlyutov, Strength of Materials. Moscow: Nauka, 1986.

[2] C. Michoud et al., "Experiences from site-specific landslide early warning systems", Nat. Hazards Earth Syst. Sci., no. 13, pp. 2659-2673, 2013. doi: 10.5194/nhess-13-2659-2013

[3] Q. Li et al., "Evaluation model of landslide lake risk disposal based on CFNN", J. Appl. Sci., vol. 13, no. 10, pp. 1746-1752, 2013. doi: $10.3923 /$ jas.2013.1746.1752

[4] G. Qiao et al., "Landslide investigation with remote sensing and sensor network: from susceptibility mapping and scaled-down simulation towards in situ sensor network design", Remote Sensing, vol. 5, no. 9, pp. 4319-4346, 2013. doi: $10.3390 / \mathrm{rs} 5094319$

[5] S. Tsybulnyk, "Improvement of means of functional diagnostics and protection of tanks on the basis of simulation", Ph.D dissertation, NTUU KPI, Kyiv, Ukraine, 2016.

[6] A. Duhanov and O. Medvedeva, Simulation of Complex Systems: A Course of Lectures. Vladimir, Russia: Izd-vo Vladim. gos. un-ta, 2010.

[7] R. Tobon, The MoCap Book - A Practical Guide to the Art of Motion Capture. Orlando, FL: Foris Force, 2010.

[8] A. Menache, Understanding Motion Capture for Computer Animation. San Francisco: Elsevier Science \& Technology, 2011.

[9] M. Delbridge, Motion Capture in Performance: An Introduction. Basingstoke, England: Palgrave MacMillan, 2015.

[10] N. Bouraou et al., "The investigation of model of the vibration measuring channel of the complex monitoring system of vertical steel tanks", EEJET, vol. 5, no. 9, pp. 45-52, 2015. doi: 10.15587/1729-4061.2015.50980

[11] C. Reas and B. Fry, Getting Started with Processing. Sebastopol: O'Reilly Media, 2010.

С.О. Цибульник

АЛГОРИТМІЧНЕ І ПРОГРАМНЕ ЗАБЕЗПЕЧЕННЯ ВІЗУАЛІЗАЦІЇ БАГАТООСЕРЕДКОВОГО ПОШКОДЖЕННЯ

Проблематика. У наш час удосконалення діагностичних систем зосереджено в основному на підвищенні точності первинних перетворювачів, і стандартні методи відображення діагностичної інформації не завжди дають змогу однозначно оціню- 
вати технічний стан об'єктів. Реалізація нових способів візуалізації даних вимірювань із використанням новітніх інформаційних і комп'ютерних технологій, наприклад імітаційного моделювання та систем захоплення руху, є перспективним напрямом розвитку засобів моніторингу та діагностики технічного стану інженерних об'єктів, які знаходяться в складних умовах експлуатації.

Мета дослідження. Обґрунтування та розробка алгоритмічного і програмного забезпечення візуалізації даних вимірювань для системи багатокласової діагностики технічного стану інженерних об'єктів.

Методика реалізації. Мова програмування Processing є новим, але потужним інструментом створення програмного забезпечення, в тому числі для діагностичних систем нового покоління.

Результати дослідження. Розроблено алгоритмічне та програмне забезпечення для візуалізації комплексних вимірювань напружень і просторового положення, яке забезпечує обробку (перетворення) записаних у файл вихідних даних для коректного їх відображення на імітаційній моделі резервуара з урахуванням особливостей запису даних у файл, параметрів аналого-цифрового перетворювача (розрядність, вхідний діапазон), кількості датчиків інформації, яка впливає на кількість елементів тривимірної моделі для відображення даних.

Висновки. На основі мови програмування Processing, яка дає змогу працювати з тривимірною графікою, реалізовано програму відображення на геометричній моделі об'єкта даних тензометричних вимірювань, попередньо записаних у файл, а також відображення поточного просторового положення об'єкта візуалізацією виміряних кутів нахилу конструкції відносно вертикальної осі.

Ключові слова: багатоосередкове пошкодження; системи багатокласової діагностики; імітаційне моделювання; Processing.

\section{С.А. Цыбульник}

\section{АЛГОРИТМИЧЕСКОЕ И ПРОГРАММНОЕ ОБЕСПЕЧЕНИЕ ВИЗУАЛИЗАЦИИ МНОГООЧАГОВОГО ПОВРЕЖДЕНИЯ}

Проблематика. В наше время усовершенствование диагностических систем сосредоточено в основном на повышении точности первичных преобразователей, и стандартные методы отображения диагностической информации не всегда позволяют однозначно оценивать техническое состояние объектов. Реализация новых способов визуализации данных измерений с использованием новейших информационных и компьютерных технологий, например имитационного моделирования и систем захвата движения, является перспективным направлением развития средств мониторинга и диагностики технического состояния инженерных объектов, которые находятся в сложных условиях эксплуатации.

Цель исследования. Обоснование и разработка алгоритмического и программного обеспечения визуализации данных измерений для системы многоклассовой диагностики технического состояния инженерных объектов.

Методика реализации. Язык программирования Processing является новым, но мощным инструментом создания программного обеспечения, в том числе для диагностических систем нового поколения.

Результаты исследования. Разработано алгоритмическое и программное обеспечение для визуализации комплексных измерений напряжений и пространственного положения, которое обеспечивает обработку (преобразование) записанных в файл исходных данных для корректного их отображения на имитационной модели резервуара с учетом особенностей записи данных в файл, параметров аналого-цифрового преобразователя (разрядность, входной диапазон), количества датчиков информации, которая влияет на количество элементов трехмерной модели для отображения данных.

Выводы. На основе языка программирования Processing, который позволяет работать с трехмерной графикой, реализована программа отображения на геометрической модели объекта данных тензометрических измерений, предварительно записанных в файл, а также отображения текущего пространственного положения объекта путем визуализации измеренных углов наклона конструкции относительно вертикальной оси.

Ключевые слова: многоочаговое повреждение; системы многоклассовой диагностики; имитационное моделирование; Processing.

Рекомендована Радою приладобудівного факультету

КПІ ім. Ігоря Сікорського
Надійшла до редакції 20 березня 2018 року

Прийнята до публікації 6 вересня 2018 року 